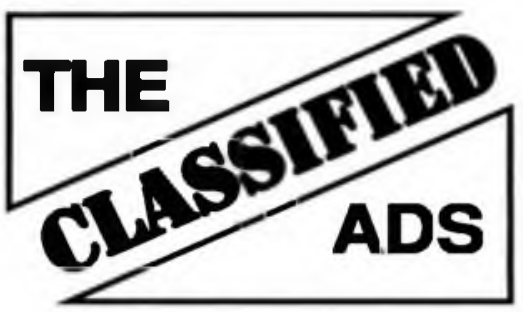

Deadl nes: Orders for regular classified advertisements must reach the ACRL office on or betore the second of the month preceding publication of the issue (e.g., September 2 for the October issue). Late job listings will be accepted on a spaceavailable basis afier the second of the month.

Rales: Classified advertisements are $\$ 6.30$ per line for insl tutiors that are ACFL members, $\$ 80$ for others. Late $j o b$ notices are \$15.25 per line for inslitutions that are ACRL members, $\$ 18.00$ for others. Organizations submitting ads will be charged according to their membership status Display ac rates range from $\$ 275$ to $\$ 565$ based upon size. Please call for sizes and rates.

Guidelines: For ads which list an application deadline, we suggest that date be no sooner than the 20th day of the month in which the notice appears (e.g., October 20 for the October issue). All job announcements should include a salary figure. Job an nouncemenis will be edited to exclude discriminatory reterences. Applicants should be aware that the terms faculty rank and status vary in meaning among institutions.

JOBLINE: Call (312) 944-6795 for late breaking job ads for academ ic and research library positions. A pre-recorded summary of positions listed with the service is revised weekly; each Friday a new lape includes all ads received by 1:00 p.m. the previous day. Each listing submitted will be carried on the recording for two weeks. The charge for each two-week listing is \$4C for ACFL members and $\$ 45$ tor non-members.

Conlaci: Ted Bales, classified advertising manager, C\&RL News Class tied Advertising Department. ACRL, American Library Association. $50 \mathrm{E}$. Huron St. Chicago, IL 60611-2795; (312) 280-2513; fax: (312) 280-Blinet:U38398@U/CMV

ALA policy requires that organizations recruiting through ALA publications or placement services comply with ALA anti-discriminalion pelicies. Policy 54.3 stales that "ALA is committed to equality of opportunity for all library employees or applicants for employment, regardless of race, color. cseed, sex, age, physical or mental han cicap, individual litestyle, or national origin By advertising through ALA services, the organization agrees to comply with this policy.

\section{POSITIONS OPEN}

ART LIBfA AFIAN, Hillyer Art Library. The Librarian of the Hillyer Art Library is iespensible for managing and direct ing a library of 60,000 volumes serving an An Depariment faculty of 25 approximately 130 majors in art history and studio and $\mathbf{9 0 0}$ students per semester, the s1atl of the Museum ol Ar, Five College laculty and sludents, alumnae, and the general public. A visual rescurces collection (slides and photographs) is administered separately by the Art Department. The Library collection, baser on a curriculum estab lished in the 1920s in Western Art, is now in process of developing in more diverse areas of Pre-Columbian, Atrican, and Asian art. Callection davelopment with more than 1,800 purchases per year, is the joint responsiblity of the Depanment and the Librarian Qualif cations: BA in arl history: MLS from an ALA-accredited institution; tive years experience in a museum or academic library; knowlecge of computerized resources in the tield of art; working knowledge of toreign languages, preferable German; cataloging background desirable: MA in art history desirable. Salary: Commensurate with experience, with a minimum of $\$ 35,320$. Review of applications will begin on March 1, 1992, and will continue until the position is filled. Send resume, and names of three references to: Employment Group, OHlice of Human Resources, Smith College, Enx 73C, Northampton, MA 01063. An affirmative action, equal opportunity institution. Minorities and women are encouraged to apply.

BIBLIOGRAPHIC SERVICES LIBRAFIAN, Northeastern Universiry. Boston. Provide reference and related information services. Prepare and delver bibliographic instruction seminars. Conduct online and other technology based searches. Serve as liaison to one or more acacemic programs as assigned and identity curriculum and research directions. In assigned subject areas, prepare and maintain currency of collection development statements, evaluate the collections, select materials within allotted budget, and identify items needing deselection, preservation, or replacement. Participate in the planning and implementation of innovative services and automated operations. Service desk schedules include some evening and weekend hours, rotating with other statt. MLS from an ALA-accredited program. Two years of experience, preferably in an academic library. Working knowledge of print and online reference sources in two or more broad academic areas. Some experience with collections policy development, selection and analysis, and with bibliographic instruction. Sell-motivated, service-oriented, and resourceful. Strong organization, analytical, planning, interpersonal, and oral and written communication skills. Krowledge of instructional and scholarly research methodologies and of trends in academic libraries and higher education. Salary: $\$ 22,625$ grade minimum, depending on qualifications and experience. Applications received by February 28, 1992, will receive first consiceration Please submit letter of application, resume, and the names, addresses, and phone numbers of three references to: Lynda Leahy, Associate Dean, User Services and Collection Developmeni, Norheaslem University Libraries, 320 Snell Library, 360 Huntington Ave. Boston, MA 02115. Northeastern University is an athirmative action. equal opponunity employer.

CAMPUS LIBfafIAN, WSU Spokane. Open March 1992. Under direction of the Extended Campus Library Services Head (Pullman campus) and the WSU Spokare campus Dean, administers the WSU Spokane Library which is in its early developmental stages. Within this excitıng environment of program building, this position provides reference service to library users. Selects staff and provides for their training and development. Assists in preparation of library budget: acministers budget Davelops and maintains strong liaisons with WSU Spokane leaching laculty, campus Dean and Extended Campus Library Services Head. Gathers and reports management data. Assesses library service and materials needs for the Spokane campus, in cooperation with faculty (both in Spokane and Pullman]. Spokane students and staft ops Maintains core collection which supports Spokane curricula. Conducts user education in conjunction with WSU Spokane courses : maintains current awareness of trends and developments in management and use of library materials, information access and program evaluation. Identifies and develops appropriate resource sharing agreements with other libraries in the geographic area. Takes active role in exploring and planning for cooperalive venlures with local instilutions and organizations. The work schedule will recuire some evering and weekend commitment, reflecting the strong evening instructional program. Librarians are appointed as members of the Washıngton Stale University Faculty and are expec1ec to participate actively in the University's instructional, research, and service programs. All privileges, obligations, and research responsibilities of faculty are inherent in such membership. Librarians are ranked in grades of 2, 3 and 4 , equivalent to the academic ranks of Assistant Professor, Associate Professor, and Prolessar. A progressive record of prolessional/scholarly achievement is expected of all librarians Recuired: ALA-accredited MLS. Experience in online catabase and/or CD-ROM search ing: program planning, implementation and management: and librany experience. Excellent communication and interpersonal skills. Willingnass to work a flexible schedule. Preferred: Experience in an academic library, use of computers in the delivery of intormation; reporting of management data using spreadsheet and database software; collection development; and con rdinating provision of library services in an extended campus academic environment. Salary: From \$28,000: commensurate with qualitications and experience. Rank: Librarian 2; faculty status. Benafits: TIAACCREF, 
broad insurance program 22 days vacation, 12 days/year sick leave. Application procedures: Send letter of application, resume, and names of three references to: Donna L. McCool, Associate Director for Administrative Services, Weshington State University Libraries, Pullman, WA 99164-5610. Application review begins: March 16, 1992. Washington State University is an equal opportunity, affirmative action educator and employer. Members of ethnic minorities, women, Vietnam era or disabled veterans, persons of disability, and/or persons between the ages of 40-70 are encouraged to apply.

CATALOG LIBRARIAN. The University of Nevada, Reno Library seeks librarian to perform original cataloging of monographs on all subjects in a variety of formats, and name and subject authority control work. Assists catalog technicians in resolving copy cataloging questions. Has opportunities to participate in collection development and bibliographic insinuction. Participates in library and campus governance through committees. Reports to Head of Bibliographic Control. Oualifications: ALA-accredited MLS. Preter 2 years of original cataloging experience in an academic library. Thorough knowledge of AACR2, LC classification, LCSH, and

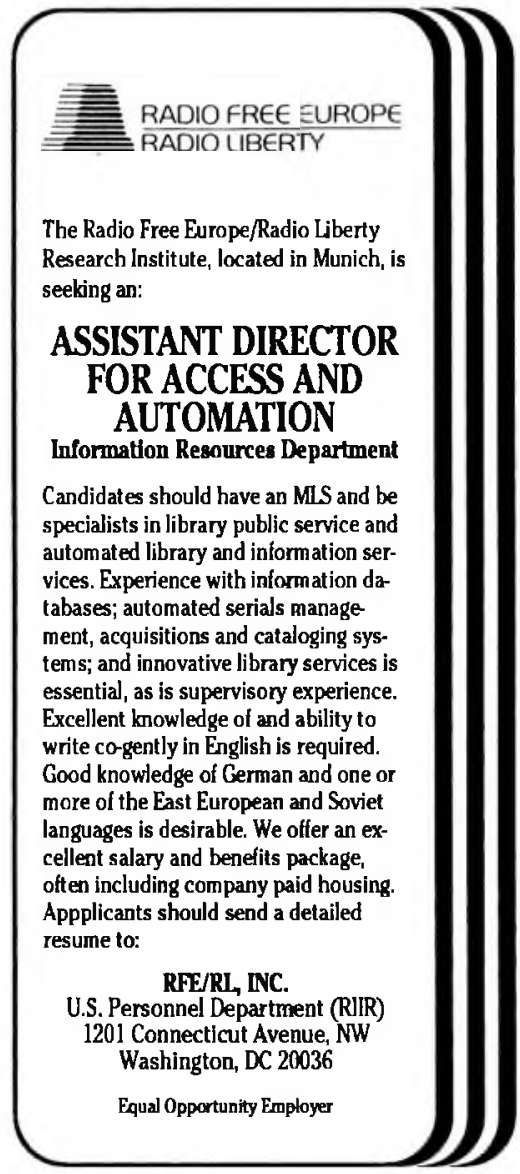

MARC formats. Familarity with a bibllographic utility. preterably PLIN or OCLC, and automated library systems. Reading knowledge of Romance languages desirable. Faculty status requires that librarians meet faculty standards for appointment, promotion, and tenure. Salary: open, depending upon qualifications and experience (minimum $\$ 30,000$ ). No state or local income tax. 12-month appointment; TIAA/CREF and other retirement options. 24 working days' vacation; generous sick leave. The University of Nevada Peno is a land-grant institution that is growing in enrollment programs and tinancial support. The University Library has a materials budget of $\$ 2.5$ Million. The University is located in Reno/ Sparks, cities of approximately 240,000 , which are conveniently located only 40 miles from Lake Tahoe and 225 miles from San Francisco. Please send resume, and names, and addresses of 3 references to: Mary Ansari, Assistant University Librarian, University of Nevada, Reno, Library/322, Reno, NV 89557. To ensure full

\section{Salary guide}

Listed below are the latest minimum starting figures recommended by state library associations and the North Carolina State Library for Protessional library posts in these states. These recommendations are intended for governmental agencies that employ librarians. The recommendations are advisory only, and ALA has not adopted recommen dations for minimum salaries. For information on librarian salaries, job seekers and employers should consider these recommended minimums, as well as other salary surveys (such as the survey in the October 15,1989 , issue of Library Journal, the ALA Survey of Librarian Salaries, the annual ARL Salary Survey, or the annual CUPA Administrative Compensation Survey) when evaluating professional vacancies. For more information, contact the ALA Office tor Library Personnel Aesources

$\begin{array}{lr}\text { Connecticut } & \$ 28,900 \\ \text { Delaware } & \$ 22,500+ \\ \text { Indiana } & \text { varies* } \\ \text { lowa } & \$ 21,588 \\ \text { Kansas } & \$ 17,500^{*} \\ \text { Louisiana } & \$ 22,000 \\ \text { Maine } & \text { varies* } \\ \text { Massachusetts } & \$ 27,554^{*} \\ \text { New Jersey } & \$ 24,200 \\ \text { New York } & \text { varies* } \\ \text { North Carolina } & \$ 22,491 \\ \text { Ohio } & \$ 20,024 \\ \text { Pennsylvania } & \$ 23,700^{*} \\ \text { Rhode Island } & \$ 26,500 \\ \text { South Carolina } & \text { varies* } \\ \text { South Dakota } & \$ 20,000 \\ \text { Texas } & \$ 25,000 \\ \text { Vermont } & \$ 22,500 \\ \text { West Virginia } & \$ 22,000 \\ \text { Wisconsin } & \$ 25,830\end{array}$

*Rather than establish one statewide salary minimum, some state associations have adopted a formula based on such variahles as comparable salaries for public school teachers in each community or the grade level of a protessional librarian post. In these cases, you may wish to contact the state association for minimum salary information.

+Salary minimums for public librarians only. 


\title{
SCIENCE BIBLIOGRAPHER
}

\section{University of Callfornia, Santa Cruz}

Associate Librarian or Librarian. Salary Range: $\$ 35,052-\$ 65,340$.UC Santa Cruz seeks an experienced bibliographer to lead its collection development program for the sciences. Reports to the Head of Collection Planning. Develops collections in assigned natural and applied science disciplines; supervises and coordinates work of other science selectors/bibliographers. Consults with faculty. As one of six subject bibliographers, participates in formulating collection policies and serves on the collection budget committee. Works closely with staff in the library's Acquisitions Section. Provides reference desk service in the Science Library six hours a week, participates in an active library instruction program and computer literature searching. Office is located in new Science Library. Participates in librarywide activities, including administrative committees and special projects.

Qualifications: Required:Graduate degree from an accredited school of librarianship; graduate level knowledge of a science discipline; substantial science collection development experience; understanding of research needs and the organization of scholarly literature; strong commitment to public service; interest in working with both undergraduate and graduate students; ability to work effectively with faculty, students, and staff in a culturally diverse environment. Preferred: graduate level knowledge of a physical science discipline; experience in training or supervision.

Deadline February 29, 1992. Applicants should supply a statement of their qualifications, a resume, and the names of four (4) references who can comment on their qualifications. Send correspondence to:

\author{
Katherine Beiers \\ AUL, P, University Library \\ University of California \\ Santa Cruz, CA 95064
}

UCSC is an affirmative action, equal opportunity employer.

consideration, applicants are encouraged to have all application information on file by $4 / 1 / 92$. Position will remain open until tilled. An AAVO employer, hiring only individuals lawtully authorized to work in the U.S.

CLASSICS LIBRARIAN. The Classics Librarian is responsible for the administration of the Classics Library and for the direction of its staff. The librarian, in cooperation with the faculty, develops and maintains research collections in the classical studies areas. The Librarian also ensures that reference, original cataloging, and online services are provided to meet the needs of faculty, students, and allied personnet in the areas served. The Librarian maintains a strong working relationship with the faculty of the Classics and related departments, with the library administration, the Arts and Humanities Council, and other related units, and engages in instructional and promotional activities of the library. Department: As a member of a decentralized library system which includes departmental libraries, the Classics Library is part of Departmental Library Services and the Arts and Humarities Council. The Classics Library, located in the Main Library building, provides services to undergraduate and graduate students and faculty of the University. The Classics Library's working collection of ca. 50,000 volumes, including ca. 400 serial titles, is complemented by extensive holdings in the Main Library's central bookstacks, the Rare Book and Special Collections Library, and other locations which make up ane of the world's significant collectlons in classical philology and classical archaeology. In addition to the librarian, the Classics Library's staff consists of one full-time staff member, and student assistants. Qualifications: Required: MLS trom an ALA-accredited school or its equivalent; minimum of three years professional experience in an academic or research library; supervisory and administrative experience; background in Classics or allied fields; ability to provide service to a diverse research-oriented clientele; strong evidence of ability to meet university standards of research, publication, and service. Preferred: Experience in collection development, cataloging, bibliographic instruction, andjor database searching; academic degree in Classics or allied fields; experience or familiarity with Latin, Geman, and one Romance language; familiarity with the needs of researchers in the tield. Salary and Rank: Salary \$28,000 upward for appointment as Assistant Protessot and $\$ 31,000$ upward tor appointment as Associate Protessor. depending on qualifications and scholarly credentials. Librarians are faculty and must demonstrate excellence in librarianship, research, publication, and university/professional/community service in order to meet university standards for tenure and promotion. Application: Send letter of application and complete resume with the names, addresses, and telephone numbers of five references to: Allen G. Dries, Library Personnel Manager, University of Illinois Library (U-C), 1408 West Gregory Drive, Urbana, IL, 61801. Phone (217) 333-5494. Deadline: April 1, 1992. The University of Illinios is an affirmative action, equal opportunity employer.

DIRECTOR. Eggleston Library and Fuqua International Communication Center of Hampden-Sydney College. Qualifications: MLS from an ALA-accredited institution; understanding of the mission of a liberal arts college; evidence of effective administrative experience in an aczdemic library; broad understanding of the operations and concepts in public and technical services; experience in collection development; demonstrable experience in working with automated systems, telecommunications, and media programs: 


\section{Dean School of Information and Library Studies}

The University of Michigan is seeking nominations and applications for the position of Dean of the School of Information and Library Studies. To position the School for a continuing leadership role in the information profession in the next century, a leader with vision, creativity, and vitality is required. The Dean is the chief academic and administrative officer of the School and reports to the Provost and Vice President for Academic Affairs. An applicant for the position should have leadership qualities, and is expected to nurture, develop, and implement cross-disciplinary education and research efforts. The Dean should have a distinguished record of scholarly research and publication, related teaching experience, knowledge of information and library studies, experience with modern information technologies, and qualifications for a tenured appointment in the School. This individual will play a major role in fundraising, and show strong commitment to affirmative action and equal opportunity.

Applications should include a detailed curriculum vitae and the names, addresses, and telephone numbers of three to five references. Applications should be submitted by February 14, 1992, but will be accepted until the position is filled. Women and minorities are especially encouraged to apply. The position will be available on July 1,1992 . Nominations and applications should be sent to:

\section{Dr. Miranda Lee Pao, Chair, Search Committee for Dean, School of Information and Library Studies, University of Michigan, 3071 Fleming Building, Ann Arbor, MI 48109-1340}

The Unversity of Michigan is an equal opportunity, affirmative action employer

ability to work productively with faculty, administration, and staff; gcod communication and interpersonal skills; awareness of emerging trends in academic libraries. Responsibilities: Management of library and communications center; establishing a new automation system; coorcination of staft and staff development; budget accountability; planning; public relations. Founded in 1776, HampdenSydney College is the nation's tenth oldest institution of higher education. Located in rural south central Virginia, Hampden-Sydney is a selective liberal arts college for men with an enrollment of 970 . The library of 170,000 volumes is staffed by five protessional and six clerical and support personnel. Competitive salary and benefits. Applicants should send a letter of application, curriculum vitae, and the names of at least three reterences to: Sandra W. Heinemann, Co-Chair, Search Committee, Box 7, Hampden-Sydney College, Hampden-Sydney, VA 23943. Applications accepted until March 15, 1992. Hampden-Sydney is an equal opportunity, aftirmative action employer.

DIRECTOR OF THE UNIVERSITY LIBRARY SYSTEM. ThE University of Pittsburgh invites nominations and applications for the position of Director of the University Library System. The University of Pittsburgh is a member of the Asseciation of American Universities, an organization of major research universities in North America. The University Library System, a member of the Association of Research Libraries, includes 18 University of Pittsburgh Libraries stafted by 94 professional librarians and holding a total collection of nearly 2.5 million volumes and over 2 million microforms, as well as over 23,000 serials. The associated libraries of the University of Pittsburgh include those of the School of Law, the four regional campuses, and the medical division. The total University collection includes over $3,200,000$ volumes, over $2,600,000$ microforms, and nearly 25,000 serials. Operating in an integrated, automated environment, the University libraries serve more than 34,000 graduate and undergraduate students and over 2,500 faculty. The director is a senior academic officer of the University and plays a leadership role in addressing Universitywide issues and programs. Qualifications for this position include: A dynamic view of the role of an academic research library and the issues facing librarianship and higher education in general; record of successful management in a complex library system, as well as in achieving the coordination, cooperation, and resource sharing required in such an environment; ability to establish and maintain effective communications relationships with library staff, faculty, administrators, students, and the external community; evidence of effective, innovative leadership in resource development; experience with using and managing library automation systems and new library technologies; appropriate educational background, including an
ALA-accredited master's level degree or equivalent. Salary is commensurate with experience. Nominations and/or applications, including current resumes and references, should be submitted no later than March 15, 1992, to: The Secretary, University Library Systems Director Search Committee, University of Pittsburgh, 826 Cathedral of Learning. Pittsburgh, PA 15260. The University of Pittsburgh is an equal opportunity, affirmative action employer.

ENGINEERING LIBRARIAN, William Jasper Kerr Library, Oregon State University. Applications and nominations are invited for the position of Engineering Librarian, Oregon State University Libraries. Responsibilities: Provides reference service with emphasis on engineering and technology from centralized reference collection; also responsible for collection development, library instruct on and liason with faculty in the College of Engineering. Required: ALAaccredited MLS degree or foreign equivalent; engineering or physical sciences degree or at least 3 years professional experience in engineering or physical sciences reference and/or collection development; strong interpersonal, oral, and written communication skills; demonstrated ability to plan and organize projects systematically and 10 follow through from implementation to completion; ability to be a flexible member of a reference team in a changing, challenging, and increasingly electronic environment; willingness to serve on University and Library committees, potential for continuing prolessional growth and scholarly accomplishment. Preterred: A graduate degree in engineering or physical sciences; foreign language competence. Appointment: Full-time, 12-month facully appointment, rank dependent upon qualifications; second master's degree required for tenure-track ; salary commensurate with qualifications, minimum $\$ 30,000$; medical/dental insurance and retirement benefits; 22 days vacation. Anticipated start date: July 1, 1992. Send letter of interest, resume, and names, addresses, and telephone numbers of three relerences to: Steven Santoyo, Personnel Officer, Kerr Library 121, Oregon State University, Corvallis, OA 973314501 by the application deadline Monday, March 9, 1992. Women and minorites are encouraged to apply and to identify themselves. Oregon State University is an aftirmative action, equal opportunity employer and has a policy of being responsive to the needs of dualcareer couples.

GOVERNMENT DOCUMENTS COORDINATOR at Brown University Library. Responsible for the management of the Library Documents section and its depository collections (U.S., U.N., and R.I.), including budgeting for the purchase of library material, processing of incoming material, ma.ntenance of documents collections, provision of reference service for these collections, and promotion of documents by means of bibliographic instruction. Reports to the 


\title{
TWO POSITIONS
}

\section{Lafayette College}

Reference Librarians: Lafayette College seeks applications for two positions to share general duties as part of a five-person reference department, with the following special responsibilities:

Electronic Information Services Librarian: Maintain, develop, and promote the use of electronic information resources and technologies. Conduct database searches and provide instruction in search technique and strategy. Provide technical support for hardware and software problems. Qualifications: ALA-accredited MLS. Knowledgeable about the uses of electronic information technologies in support of teaching and research. Strong database searching skills. Strong communications, interpersonal, and teaching skills. Some technical competence related to hardware and software.

Reference/Instruction Librarian: Take an active role in planning and implementing the Library's program of outreach and instruction. Develop classroom presentations in the use of print and electronic information resources using a variety of pedagogical approaches. Qualifications: ALA-accredited MLS. Strong communications, interpersonal, and presentation skills. Demonstrated effectiveness as a teacher. Broad knowledge of reference sources and research strategies.

Founded in 1826, Lafayette College is a highly-selective private, residential college of approximately 2,000 students and 177 faculty, unique for its combination of liberal arts and engineering in an exclusively undergraduate institution.

Write with resume, and names of three references to:

\author{
Ronald E. Robbins \\ Head of Public Services \\ Skillman Library \\ Lafayette College \\ Easton, PA 18042
}

Salary: $\$ 26,000$ minimum. Consideration of candidates will begin March 9, 1992, and continue until position is filled.

Head, Serials/Documents Depariment. Requirements: ALA-accredited MLS degree; minimum of three years professional library experience, preferably in an academic research library; experience with U.S. documents; previous supervisory experience; lamiliarity with automated library systems; undergraduate specialty in a social science discipline preferred. Appointment range: $\$ 29,550-36,900$ based upon experience. Interested candidates should send letter of application, resume and names of three reterences to: Geneva Fenrell, Dept. of Human Resources, Brown Unlversity, Box 1879/ FGR1 05, Providence, RI 02912. Applications received by March 1. 1992, will receive first consideration. Brown University is an equal opportunily, affirmative action employer.

MEAD, ACQUISITIONS DEPARTMENT, Brown University Library. Responsible for the administration of the Acquisitions Department including purchasing, budgeting, fund monitoring, gitts and exchanges, binding and related operations. Fequirements: ALAaccredited MLS degree; 3 years acquisitions or related experience in a research library, including dealing with the U.S and loreign publishing trade; proven successtul supervisory experience; excellent oral, written and interpersenal skills; thorough bibliographic skills; experience with automated systems; knowledge of library fiscal and business practices; and reading knowledge of one foreign language. Appointment range: $\$ 35,299-\$ 44,000$ based upon expe rience. Interested candidates should send letter of application, resume, and names of three references to: Geneva Ferrell, Human Resources Department, Box 1879/FGRog9, Erown University, Providence, Fl 02912. Brown University is an equal opportunity affirmative action employer.

HUMANITIES REFERENCE COLLECTION/DEVELOPMENT LIBRARIAN. Available April 1. 1992. Selects materials in Russian literature and language and in other agreed upon Humanities disciplines, dependent on training and experience. Works closely with the teaching faculty in these areas. Provides full range of genera reference services in al the Humanities and Social Sciences disciplines, including business, law, and government documents. Provides bibliographic instruction in the assigned areas and in crossdisciplinary Humanities courses. Participates in library user education program. Librarians are appointed as members of the Washington State University faculty and are expected to participate actively in the University's instructional, research, and service programs. Al privileges, obligations, and research responsibilities of faculty are inherent in such membership. Librarians are ranked in grades 2, 3, and 4, equivalent to the academic ranks of Assistant Protessor, Associate Professor, and Professor. Required: ALA-accredited MLS reading knowledge of Russian language and knowledge of Russian 


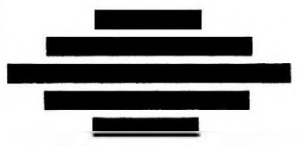

\section{University of California San Diego}

UCSD is an equal opportunity, affirmative action employer and specifically seeks candidates who can make contributions in an environment of cultural and ethnic diversity.

Assistant Head/Government Documents Group, Research Services Department, Central University Library. Rank: Associate Librarian $\$ 35,052$ - $\$ 50,496$ or Librarian I - IV $\$ 47,124$ - 59,316. Responsibilities: Under the general direction of the Department Head, the Assistant Head/Government Documents Group provides administrative and programmatic leadership for the department's Government Documents Group and serves as Federal Depository Librarian. Duties include primary responsibility for developing and maintaining programs related to accessing government information, employing both traditional and new services and technologies; training, supervising, and evaluating unit members (1.5 FTE Librarians and 3.0 FTE Library Assistants); training and evaluating additional public services staff for work with a government documents collection of 600,000 pieces; working with the Department Head and other Assistant Heads to plan, develop, and manage a variety of reference sources and services; and maintaining awareness of trends in academic library public services. The successful candidate will be the primary selector for the U.S. documents collection and will participate in national discussions of government publications and information policy. Qualifications: Required:M.L.S. degree, ability to work in and to promote a culturally diverse environment, experience in providing public service for government documents, and experience selecting U.S. documents. Highly desirable: strong interpersonal and communication skills, capability of working effectively in an automated environment, including online catalogs, CD-ROMs, and local area networks; and successful experience in (or other evidence of capability for) effective supervision. Desirable: awareness of trends in academic library public services. Appointment at the Librarian rank requires substantial relevant experience.

Special Collection Cataloger/Head, Technical Services, Mandeville Department of Special Collections. Rank: Assistant Librarian, $\$ 26,668$ - $\$ 36,696$ or Associate Librarian $\$ 35,052$ - $\$ 50,496$. Responsibilities: Under the direction of the Head of Special Collections, this librarian has both cataloging and technical services responsibilities. In accordance with the policies and procedures of the UCSD Library, will be responsible for the original cataloging and classifying of books and non-book materials in the Department of Special Collections, providing bibliographic description and access points according to AACR2, Descriptive Cataloging of Rare Books, and other rules for cataloging special materials. Manages and supervises cataloging and technical services functions within the department, including acquisitions and catalog maintenance. Supervises a unit that currently includes $2.5 \mathrm{FTE}$ paraprofessionals and 4 students. Acts as departmental liaison to the Library's Systems Department. Represents the department on the Library's Technical Services Advisory Committee and its Cataloging Committee. Participates in department's delivery of public services, as well as in developing departmental policies and procedures. Assists in the preparation and implementation of grant proposals to fund selected bibliographic projects. Qualifications: MLS degree. Knowledge of and skill in application of AACR2, LCSH, LC classification, Descriptive Cataloging of Rare Books, MARC formats, and all other national and international trends in bibliographic control of special collections. Highly desirable qualifications include experience with rare book/special collections cataloging, knowledge of APPM and the AMC format, experience with OCLC, knowledge of Latin and at least two modern European languages, familiarity with automated cataloging, and supervisory experience. Excellent oral and written communications skills are required. An appointee at the Associate level would be expected to bring to the position well-developed cataloging skills and some experience in an academic library or research institution.

(continued on next page) 
(continued from previous page)

Head, Original Cataloging Section, Catalog Department, Central University Library. Rank: Associate Librarian, $\$ 35,052-\$ 50,496$ or Librarian I-IV, $\$ 47,124-\$ 59,316$. Responsibilities: The Original Cataloging Section Head will provide management, leadership, supervision, and staff development for members of the Original Cataioging Section as well as provide some original monographic cataloging. This individual will be responsible for planning and directing the activities of the Original Section and actively participating as a member of the Department's management team, reporting directly to the Catalog Department Head. We seek someone who has excellent communication and interpersonal skills, someone who can plan innovative approaches to processing efforts in order to provide faster availability of materials in our automated environment, and someone to serve as the NACO Coordinator for the UCSD Libraries. Qualifications: Required: MLS degree, demonstrated successful leadership experience, effective communication skills, cataloging experience for monographs, and experience working in an online environment. Preferred: Knowledge of German (or other western European languages), OCLC and NACO experience, awareness of national and international trends in cataloging and bibliographic control, demonstrated organizational abilities, initiative, strong interpersonal skills, and ffexibility. Appointees at the rank of Librarian will be expected to bring substantial relevant experience and expertise to the position.

Head, Serials Cataloging Section, Catalog Department, Central University Library. Rank: Assistant Librarian, $\$ 26,668$ - $\$ 36,696$ or Associate Librarian I - IV, $\$ 35,052$ - $\$ 41,160$. Responsibilities: The Serials Section Head will provide management, leadership, supervision, and staft development for members of the Serials Section as well as perform original serials cataloging. This individual will be responsible for planning and directing the activities of the Serials Section and will actively participate as a member of the Department's management team, reporting directly to the Catalog Department Head. We seek a person with excellent communication and interpersonal skills, someone to facilitate innovative approaches to processing in our online environment to expedite availability of materials, and someone to serve as the serials cataloging resource person for the UCSD Libraries. Qualifications: Required: MLS degree, demonstrated successful leadership experience, effective communication skills, cataloging experience.Preferred: Knowledge of any foreign language, OCLC experience, experience working in an online environment, awareness of national and international trends in cataloging and bibliographic control, demonstrated organizational abilities, initiative, strong interpersonal skills, and flexibility. Appointment at the Associate rank requires substantial relevant experience.

For all positions: UCSD librarians are expected to participate in librarywide planning and to be active professionally. Applications received by $3 / 31 / 92$ will be assured of consideration. To apply send a resumé, cover letter, and list of three references to:

University of California, San Diego Janet Tait, Academic Personnel Coordinator Library Personnel, 0175H-1 9500 Gilman Dr. La Jolla, CA 92093-0175. 


\title{
COLLECTION DEVELOPMENT LIBRARIAN/ MANAGER OF COLLECTION SERVICES (SEARCH EXTENDED)
}

\author{
Bucknell University
}

Wanted: Innovative librarian to revitalize collection development program, integrating traditional print collections with non-print and computer-based information resources. Reporting to the Director, this key position will develop and manage the program, foster ongoing collaborative relationship between faculty and librarians, and provide leadership and support for the collection development activities of each Bucknell librarian (14 total). Actively participates in librarywide planning and policy making.

Required: ALA-accredited MLS; substantial experience in academic librarianship; ability to motivate and develop staff in a matrix environment; strong communication skills; demonstrated analytical and planning abilities. Liberal arts background preferred. Hiring Range: low to mid-thirties.

For maximum consideration, submit letter of interest, resume, and names, and phone numbers of three references by March 23, 1992, to:

\author{
Ann de Klerk \\ Director of Library Services, Room 203 \\ Ellen Clarke Bertrand Library \\ Bucknell University, Lewisburg, PA 17837
}

Applications from members of minority groups are encouraged.

literature; academic degree in one of the Humanities; strong interpersonal and communication skills. Preferted: Recent humanities reference experience in an academic/research library; master's or above degree in one of the Humanities; experience with user education and automated systems. Salary: From $\$ 22,000$, commensurate with qualifications and experience. Rank: Commensurate with qualifications and experience; tull faculty status. Benefits: TIAACREF, broad insurance programs, 22 days vacation, 12 days/ year sick leave. Application Procedures: Send letter of application, resume, and names of three (3) references to: Donna L. McCool, Associate Director for Administrative Services, Libraries, Washington State University, Pullman, WA 99164-5610. Applicatıon review to begin: March 6, 1992 . Washington State University is an equal opportunity, affirmative action educator and employer. Protected group members are encouraged to apply.

LIBFARIAN. Instruction librarian to give innovative direction to tired instruction program and to participate in some combination of reference, collection development, database searching, etc. as a "Compleat Librarian." Business or science experience a plus. We are looking for a selt-motivated individual who has some library instruction experience, an ALA-accredited MLS, and an interest in working in an environment that emphasizes peer responsibilities and relationships. We have been successful in developing positions that give individuals a good breadth of involvement in library services and operations. The library has 10 librarians and 18 staff. an integrated library system, 350,000 volumes, and 1,900 subscriptions for 5,000 students and 200 plus faculty. Tenure track position with faculty status, rank dependent upon qualifications. Tenure will require a second Master's and scholarly activity. Excellent benetits include TIAA; 12 -month contract. Minimum salary $\$ 33,000$. Review of applications will begin February 15; deadline for applications is March 1; largeted starting date is July 1, 1992. If you believe your background might fit our needs and if our kind of "compleat" envirenment appeals to you, please apply with letter, resume, and names, addresses, telephone numbers for three references 10 : Hoss Stephen, Director of Library Services, Fider College Library, 2083 Lawrenceville Road, Lawrenceville, NJ 08648-3099. Rider College is an affirmative action/equal opportunity employer.
LIBRARIAN/CATALOGER. Southwest State invites application for full-time position to begin by April 1, 1992. Librarian will coordinate cataloging cperation and computer technologies, complete original cataloging, edit OCLC records, serve as systems librarian for PALS network. Master's in Library Science required (ALA program preferred). Experience should include MARC record format, LC authority records, OCLC formats, AACR2, and automated library systems skills. Position is subject to final budgetary approval. Send letter of application, resume, transcript and name, address, and phone number of three references to: Director of Personnel Services, Southwest State University, Marshall, MN 56258. Review of applications will begin February 17, 1992, and continue until position is filled. Southwest State University encourages applications from women and people of color

LIBAARY DIRECTOR, Historical Society of Pennsylvania (Search reopened). To manage 500,000 volume reference and genealogical collection with primary and secondary source materials relating to the Delaware Valley region and to the original thirteen states. The Director supervises all Library functions including collecting, preserving, and making holdings available tor use. Staff of eight full and part-time employees. Qualifications: Minimum of five years experience in Library management including financial and supervision responsibility; MLS desirable; background in American History and genealogy; and good interpersonal and communication skills. EOE. Salary: $\$ 30$ s. Apply to: President's Ottice, Historical Society of Pennsylvania, 1300 Lccust Street, Philadelphia, PA 19107. Application deadline March 1.

LIBRARY DIAECTOR. Exciting opportunity for an experienced, energetic, imaginative librarian to spend one year in Bulgaria. Plan and organize library services for the newly created American University in Bulgaria (AUBG), which has been established with the assistance of the University of Maine. The AUBG is a recently incorporated institution of higher education located in Blagoevgrad. a city of 75,000 , approximately $80 \mathrm{~km}$ southwesl of Sofia. The University opened in October 1991, with an entering class of 208 students. Approximately $90 \%$ of the first year class are Bulgarian citizens; the remainder are internaticnal students. The University 
will grow to a student body of 1,200 by its fourth year of operation. Proposed major areas of study include: American Studies, Applied Economics, Business Administration, Computer Science, English Language and Literature, Public Administration, Political Science, Journalism and Mass Communication. All instruction is in English. At present there is space tor a library at AUBG but no library collection exists. The Library Director will report to the Acting President and will have responsibility lor all aspects of library service: space planning, staffing, development of policies and procedures, selection of library materials, technical and public services. Qualifications: ALA-accredited MLS; at least 3-5 years of academic library experience, including supervisory experience; broad knowledge of academic library functions; excellent organizational and communication skills; demonstrated initiative and ability to set and achieve goals; strong interest and hands-on experience in the application of current information technology in the delivery of library services; ability to function in a cross-cultural environment. One year appointment. Salary: $\$ 35,000$. Benefits include TIAA/CREF, life and healih insurance. Send cover letter; resume; names, addresses, and telephone numbers of 3 references to: AUBG Library Director Selection Committee, University of Maine, Raymond H. Fogler Library, Orono, ME 04469. FAX 207-581-1653. AAVOE

MUSIC LIBRARIAN, Saint Olaf College. Leave replacement (to stant work as soon as possible and continue until June 30, 1994). The Music Librarian is responsible for the operation of the Music Library, including collection development, some original cataloging of scores and sound recordings, reference, bibliographic instruction, supervision of staff, and liaison with faculty and administration. Additional work as liaison to the dance and art departments. St. Olaf College is a four-year liberal arts undergraduate college of the Evangelical Lutheran Church of America located approximately 35 miles south of Minneapolis with an enrollment of 3,000 students. The Music Library is located in the Music Building and houses 22,000 books and scores and 9,000 sound recordings. Staff

\section{TRENTON STATE COLLEGE}

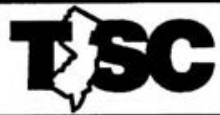

\section{ASSISTANT DIRECTOR LIBRARY TECHNICAL SERVICES}

Reporting to the Director of Library Services, the Assistant Director is responsible for the management and coordination of all units of technical services: Periodicals, Cataloging, and Acquisitions. Includes the integration and improvement of computer-based library systems, and liaison to the campus computing center. Participates in planning; budget issues, staffing and equipment needs, program development, policy making.

Qualifications: Requires ALA-accredited MLS, and substantial experience with a major integrated library system, preferable NOTIS, and currency in other academic library technologies. Preferred: added experience in project management including budget control, wider supervision, and wider professional work in a major area of technical services, preferably cataloging with OCLC.

Salary Rande: $\$ 38,000-\$ 56,000$, TLAACREF. Submit letter of application with resume, and names, telephone numbers, and addresses of three professional references to: $H$. Duncan Wall, Interim Director, R.L. West Library, Trenton State College, Hillwood Lakes, CN4700, Trenton, NJ 08650-4700. Extended profile will be mailed in response to all inquiries: (609) 7712332, FAX: (609) 771-3299. Review of all applications will end March 15, 1992. To enrich education through diversity. TSS is an AA/FOF. includes 1.15 FTE support staff, and student assistants. Qualifications: Undergraduate degree in music; MLS from an ALA-accredited library school. Familiarity with AACR-2, MARC formals in music, and LC classification. Library experience and graduate work in music desirable. Good communication skills essential. Salary Minimum salary of $\$ 28,000$ annually for a 10 -month appointment Apply: Applications accepted through March 20, 1992. Send letter of application, resume, transcripts, and the names of three references to: Beth Christensen, College Librarian, Rolvaag Memorial Library. St. Olaf College, 1510 St. Olaf Avenue, Northfield, MN 55057-1097; (507) 663-3225. St. Olaf College is an equal opportu nity employer.

PROCESSING ARCHIVIST, Louisiana State University. The Louisiana and Lower Mississippi Valley Collections is an integrated research collection of books, journals, manuscripts, microtorms, maps, photographs, university archives, and other special formals documenting the history and culture of Louisiana and the lowe Mississippi Valley. It is a Department with the LSU Libraries division of Special Collections and is located in Hill Memorial Library. Responsibilities: Under the supervision of the Head Technical Services, Louisiana and Lower Mississippi Valley Collections, the incumbent is responsible for: arrangement and description of manuscripts and archives; the creation of MARC AMC cata oging records; assisting with name authority work; accessioning manuscript materials; reterence desk duty; other duties as as signed. Required Qualifications: A master's degree in librarianship from a program accredited by the American Library Association, or a master's degree in history or a related discipline with course work or other formal education in archives administration; minimum of one year protessional experience in processing and cataloging manuscripts and archives; evidence of the potential to meet the criteria for promotion and tenure. Preferred Qualifications: Experience with MARC AMC; experience with archival databases; membership in the Academy of Certified Archivists. Salary: Competitive, commensurate with experience and qualifications, $\$ 24,000$ minimum. Standard benetits and optional retirement package. Send a letier of application, complete curriculum vitae, and the names, addresses, and telephone numbers of at least three relerences to: Chair, Processing Archivis! Search Committee, LSU Libraries, Louisiana State Universily, Baton Rouge, LA 708033300 . Position open until filled; review of applications will begin March 1, 1992. LSU is an AAVEO institution.

PUBLIC SERVICES LIBRARIAN, Oberlin College Conservatory of Music Library. Responsible for coordinating reterence and círculation services, interlibrary loan, and bıbliographic instruction in one of the nation's leading music libraries. Supervises 1.5 FTE administrative assistants. Requited: Master's in librarianship, substantial educational background in music, familiarity with online systems, one or more Western European languages, strong service commitment. Desired: professional music reference experience, advanced training in musical scholarship, superviscry expe rience. Salary competitive, commensurate with qualifications and experience, $\$ 24,500$ minimum. Generous benefits. Send letter of application, resume, and names, addresses, and telephone numbers of three references to: Chair, Conservatory Public Services Librarian Search Committee, Oberlln College Library, Mudd Center, Oberlin, $\mathrm{OH}$ 44074. Review of applications will begin on February 28, 1992. AAVEOE

REFERENCE LIBRARIAN/CATALOGEF, Penn State Harrisburg Creative, flexible librarian to provide general reference and nonprint cataloging services in the Heindel Library of Penn State Harrisburg, an upper-division and graduate college of the Pennsylvania State University. This is a faculty position, with approximately two-thirds time devoted to relerence duties, including desk coverage (with scheduled evening and weekend hours), research assistance, bibliographic instruction, online and CD-ROM literature searching, and collection development. Technical service responsibilities include original and copy cataloging on non-print materials in all formats, providing guidance in processing. and acting as liaison between public and technical services for nonprint materials. Successtul candidate will demonstrate ability to work eflec tively with students, faculty, slaff, and administrators. Campus Facts: Located in the Harrisburg metropolitan area; approximately 2,200 upper-division and 1,200 graduate students; 140 faculty Collections include 230,000 volumes; 975,000 microtorms; 1,550 periodical subscriptions. Qualifications: Requires ALA-accredited MLS, or equivalent, plus two years' professional experience as a 


\title{
Kalamazoo College
}

Kalamazoo College, a highly selective liberal arts college, seeks a creative, future-oriented director for its Upjohn Library. Located in Kalamazoo, Michigan, a culturally rich city in a metropolitan area of 225,000 with easy access to Detroit and Chicago, the College offers a coherent undergraduate experience which interweaves a traditional liberal arts curriculum with experiential education in both domestic and international settings.

The library, with a collection of over 285,000 units of print and non-print media, provides the scholarly resources for an increasingly diverse patron base of 1,260 students and 120 faculty and, through reciprocal agreements, shares its resources with area colleges and universities. Automated with INNOPAC, a fully integrated library system, the library offers a full range of media and electronic reference services. The campus and the catalog are Internet accessible.

Responsibilities of the director include: supervision of the staff and services of the library, its separately located media center, and the college archives; selection, organization, and maintenance of the collections; recruitment and training of a staff of $13.5 \mathrm{FTE}$; advocacy for the library with faculty, administration, and the larger community. The director will also be expected to engage the services and resources of the library in an ongoing institutional commitment to racial, ethnic, and gender understanding. The library director is a non-tenured member of the faculty and reports to the Provost. Salary for this twelve-month contract is negotiable depending on qualifications, with a minimum salary of $\$ 46,000$.

The successful candidate must have an ALA-accredited MLS with several years of administrative experience in an academic library; leadership in building a collection balanced with respect to disciplines and media; substantial experience with online public access catalogs and electronic information resources; strong interpersonal skills, a strong service orientation, and demonstrated understanding of the role of library and media services in a small, independent liberal arts college.

Applications should include a letter of application, a complete resume, and the names of references. Review of applications and nominations will begin February 14, 1992, and will continue until an appointment is made. Please send all correspondence to:

\author{
Personnel Office \\ Attn: M. J. La Plante \\ Kalamazoo College \\ Kalamazoo, Ml 49006
}

An equal opportunity, aftirmative action employer.

public service librarian, preferably in an academic library, and entrylevel calaloging knowledge. Additional advanced degree and microcomputer skills desirable. Potential for promotion and tenure wil. be considered. Salary and academic rank dependent on qualifications; $\$ 26,000$ minimum. Benefits include liberal vacation and sick leave; excellent insurance; State or TIAA/CREF retirement options; and educational privileges. To apply: Send letter, current resume, and names of three reterences to: Sandra Jackson, Box LIB-3, Penn Stale Harrlsburg, Middletown, PA 17057-4898. Applications will be reviewed beginning March 20,1992, and continue until position is filled. An atfirmative action, equal opportunity employer. Women and minorities are encouraged to apply.

REFERENCE LIBRARIAN FOR AMERICAN STUDIES. SUbject specialist in American Studies including North American history and ethnic studies, including studies related to African-, Hispanic-, and Asian-Americans and other people of color. Collectıon development responsibilities include selection and evaluation and faculty liaison. Reference duties include reference assistance, bibliographic instruction, orientation and database searching. Requirements: ALAaccredited MLS, subject master's degree required for tenure. Degree in American Studies or American History prelerred. Ability to work in a multi-disciplinary environment necessary. Two years public service experience in an academic or research library and knowledge of electronic services desirable. Salary/benefits: faculty status, attractive benefits package including five weeks annual vacation. Salary commensurate with experience and background, minimum: $\$ 30,000$. To ensure consideration send resume and letter of application, including the names, addresses, and telephone numbers of three references by January 31, 1992, to: Alice Deich, Personnel Manager, New York University Libraries, 70 Washington Square South, New York, NY 10012. New York Univarsity encourages applications from women and members of minority groups. 


\title{
ASSOCIATE DEAN,TECHNICAL SERVICES AND SYSTEMS DEVELOPMENT
}

\section{$\boldsymbol{N}$ Northeastern University}

\author{
Northeastern University
}

Responsibilities: Plan, administer, and provide leadership for the technical services and systems development functions of the Northeastern University Libraries. Effectively organize staft, utilize fiscal and technological resources, and give direction to departmental units for acquisitions/serials, cataloging, networked support systems, and archives/special collections. Work closely with Dean and other administrative officers on strategic, long-range, and general administrative planning, on policy formulation, and on funding, budgeting, and grants. Coordinate plans and activities with user services, collection development, and administrative services. Represent the University Libraries regionally and nationally on technical services and automated support systems matters.

A new, centralized library on the Boston campus opened in 1990. Annual acquisitions purchases exceed \$3.5 million. The Libraries hold membership in OCLC, Nelinet, and the Boston Library Consortium. CARL Systems and Tandem computers are the platforms for the public access Northeastern University Libraries Information System (NULIS) and for integrated processing services support. NULIS also serves as the Libraries', primary network gateway to other information resources.

Qualifications:ALA-accredited MLS degree. At least five years of substantial managerial experience in automated technical services and in analysis, planning, and implementation of systems and networks. Strong administrative leadership, communication, interpersonal, analytical, planning, and organizational skills. Able to work effectively with individuals and groups from among various academic, administrative, and library constifuencies, and to articulate and advocate goals and innovative programs. Thorough understanding of concepts of technical services and of automated information services support in academic libraries. Knowledgeable about trends in higher education, in academic libraries, and in emerging relevant technologies and support systems. Commitment to professional growth and staff development.

Salary: $\$ 60,000$ minimum, depending upon qualifications and experience. Excellent benefits package

Applications received by March 6, 1992, will receive first consideration in this reopened search. Please send a letter of application, resume, and the names of three references to:

\author{
Alan R. Benenfeld, Dean \\ Northeastern University Libraries \\ 320 Snell Library \\ 360 Huntington Avenue \\ Boston, MA 02115
}

Northeastern University is an affirmative action, equal opportunity employer.

REFERENCE LIBRAFIAN/HUMANITIES. Under the direction of the Head of Reference, the Reference Librarian will provide general academic reference service including some evenings and weekends. Responsibilities will include bibliographic instruction to library users and online searching. The Reference Librarian wils participate in collection development for literature and the fine arts. Qualifications include an MLS from an ALA-accredited school or the foreign equivalent, strong commitment to public services in an academic setting, demonstrable ability and desire to work closely and proactively with students, effective interpersonal and communications skills, and a familiarity with online searching and CD-ROM products. Desirable qualifications include an academic background in the humanities and experience in providing reference service in an academic library. The position is tenure-track with taculty rank and status. Successful applicants must have or complete a second Master's degree for tenure and show potential to gain promotion through faculty ranks. Position is available beginning February 1 , 1992; minimum salary: $\$ 29,000$. Benefits include: TIAA-CREF 


\section{Curator of Manuscripts Harvard College Library}

Reporting to the Librarian of the Houghton Library, the Curator provides imaginative leadership for one of the world's pre-eminent collections of manuscripts. The collections, over 5,000,000 items, comprise papyri, early European manuscripts, extensive literary manuscripts (including the most significant archive of nineteenthand (wentieth-century American literature), publishing records, photographs, musical scores, philosophical writings, and political, missionary, and other historical materials.

The Curator is responsible for the development, cataloging, and conservation of the collections, and for fundraising, scholarship, teaching, exhibitions, and publications based on the collections. The Department maintains an ambitious acquisitions program through purchase, gift, and bequest. The Curator will assume responsibility for introducing electronic cataloging and broadening access through the national utilities.

Qualifications: an advanced degree in an academic discipline related to the holdings; successful experience within special collections or comparable area; distinction in one's scholarly work; the ability to supervise department members and to work in concert with colleagues in other departments to further the educational and research mission of the Library as a whole.

Anticipated hiring salary: $\mathrm{mid} 50 \mathrm{~s}$

Available: Spring 1992

Major Benefits: One month's vacation; generous holiday and sick leave; choice of health plans; dental insurance; life insurance; University-funded retirement Income Plan; tax-deferred annuity options; tuition assistance.

The Search Committee will begin screening applications on February 1, 1992 and will continue until the position is filled.

To apply, please send a letter of interest, resume and the names of three references to: Hazel C. Stamps, Director of Personnel Services, Harvard College Library, Widener 188, Cambridge, MA 02138. Harvard University upholds a commitment to Affirmative Action and Equal Opportunity.

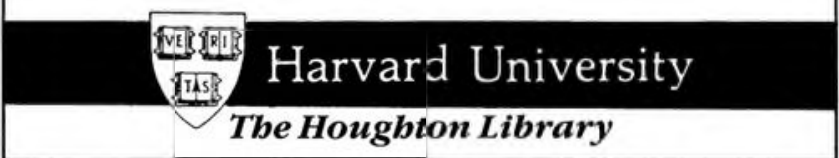

retirement, medical, dental plans, full tuition remission at USD, including graduate school. Deadline extended. Applications must be postmarked by March 2, 1992, to be considered. Submit letter of application and resume, with names, addresses, and telephone numbers of three professional references to: Tony Harvell, Head of Reference, Copley Library, University of San Diego, Alcala Park, San Diego, CA 92110. A Catholic university, USD has 6,000 students and is an AAVO employer. Applications encouraged from minorities.
REFERENCE LIBRARIAN for dynamic, service-oriented program of humanities and social sciences reference in an outstanding college library. Required: ALAMLS, sound liberal arts education, academic library reference experience, demonsirated service commitment, excellent interpersonal and communication skills. Preferred: experience with library instruction, electronic information sources, interlibrary loan, and government documents; knowledge of one or more toreign languages. Oberlin College combines a leading undergraduate college of arts and sciences with a music 


\title{
HUMANITIES BIBLIOGRAPHER
}

\author{
Tufts University
}

Tufts University, Medford, Massachusetts, seeks qualified applicants for the position of Humanities Bibliographer. Reporting to the Assistant Director for Collections and Technical Services, this new fulltime position will be part of the collection development and management program. The purpose of the position is to create, administer, and maintain the Library's collections on a subject-specific basis, with full intellectual and fiscal responsibility.

Responsibilities: Administers library materials funds for American and English Languages and Literatures, Art and Architecture, Classics/Archaeology, Drama/Dance, Modern Foreign Languages and Literatures, and Philosophy/Religion. Exercises full responsibility for title selection and allocation of individual subject-specific funds. Develops collection development policies. Communicates and interprets Library policy as needed. Acts as a liaison with relevant faculties, students, and staff. Participates in the development of policies and procedures through committee work, and acts as a resource person for humanities-related collection development and management, both individually and through scheduled meetings and discussions. Conducts serials reviews, collection evaluations and relocations. Prepares annual materials budget rationale. Processes gifts.

Additional responsibilities for this position will include management of the daily operations of the University Archives. While NOT acting as an archivist, this position will supervise existing staff, the servicing of existing collections, and the development of all policies, procedures, and budget recommendations for staff, supplies, and ongoing operations.

Qualifications: An ALA-accredited MLS is required. An undergraduate degree in one of the humanities and previous experience in collection development and management will receive strong preference.

Appointment will be made commensurate with experience and qualifications. Send letter of application, including resume and names and addresses of 3 references to:

\section{Sonia Payne \\ Arts and Sciences Library \\ Tufts University \\ Medford, MA 02155}

Screening for this position will begin on March $\mathbf{3 0}$ and continue until the position is filled.

Tutts University is an equal opportunity/affimative action employer.

school of national prominence. The library contains over 1 million volumes and is fully automated. Salary competitive, commensurate with qualifications and experience, $\$ 24,500$ minimum. Generous benefits. To ensure consideration, send letter of application, resume, and names, addresses, and telephone numbers of three references by March 27, 1992 to: Chair, Reference Librarian Search Committee, Oberlin College Library, Mudd Center, Oberlin, $\mathrm{OH}$ 44074. AAIEOE

SCIENCE AND ENGINEERING LIBRARIAN. The University of Alabama seeks applications for the position of Science and Engineering Reterence Librarian. Responsibilities: Assists in providing informationa|/instructional assistance to faculty, students, staff, and other users of the Eric and Sarah Rodgers Library for Science and Engineering. Specific duties will include reference desk assignment, database and end-user searching and instruction, library user instruction, collection development and faculty liaison, and similar duties as assigned. Evening and weekend service on a rolating basis. This position reports to the Head of the Science and
Engineering Library. Qualifications: Required: An MLS from a program accredited by ALA (degree must be earned by the close of the application period); knowledge of basic and science or engineering reterence sources, national and Irade bibliographies; aca demic background or library reference experience in science or engineering: ability to work effectively with faculty, students, and library personnel at all levels; excellent oral and written communication skills; evidence of, or potential for, professional and/or scholarly activity: commitment to client-centered service. Preferred: Reference experlence; degree in a science or engineering discipline; familiarity with microcomputer applications for libraries Experience searching CD-ROM and other electronic databases. Environment: The Eric and Sarah Hodgers Library for Science and Engineering was completed in 1990 and is a departmental library within the University of Alabama Libraries system. This 43,000 square foot state-ot-the-art lacility makes maximum use of computer-based information systems to serve the needs of about 250 faculty members in engineering, the nalural sciences and mathematics and approximately 3,000 undergraduate and graduate 


\section{Hebraica Cataloger}

Reporting to the Head of the Judaica Division (a vertically integrated unit). Works primarily in the area of technical services with emphasis on materials in Hebrew. Performs on-line original cataloging covering all areas of Jewish Studies. Assists in collection development and in reference service.

A world class collection of Jewish Studies materials, located in Widener Library, the Division maintains comprehensive collection development, technical and public service programs

Requirements: MLS from an ALA-accredited library school or its equivalent, or at least one year's cataloging experience working with Hebraica in an integrated on-line research library environment required. Fluent Hebrew and English required; reading knowledge of Yiddish and at least one other European language highly desirable. Working knowledge of OCLC, AACR2, LC classification and subject headings systems, and MARC format required. Ability to learn quickly, communicate effectively, and function with considerable autonomy within a fast-paced, goal-oriented, productivity-conscious environment.

Anticipated Hiring Salary: mid 30's Available: Immediately

Major Benefits: One month's vacation; generous holiday and sick leave; choice of health plans; dental insurance; life insurance; University-funded Retirement Income Plan; tax-deferred annuity options; tuition assistance.

Interested candidates may send a cover letter and the names of three references to: Hazel C. Stamps, Director of Personnel Services, Harvard College Library, Widener 188, Cambridge, MA 02138. Harvard University upholds a commitment to Affirmative Action and Equal Opportunity.

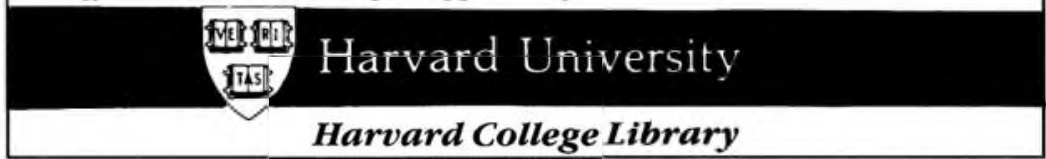

stucents in these disciplines. The library's holdings include 200,000 volumes, 1,800 current serials, and 62,000 microtorms. The stafi consists of four protessional librarians, four support stall, and student assistants. The University of Alabama Libraries are a member of ARL, CRL, SOLINET, and the Network of Alabama Academic Ljbraries and have implemented the public access catalog, catalog. ing, and circulation functions of the NOTIS system. Salary/Bentits: Salary and rank are dependent upon experience and qualirications: Instructor or Assistant Protessor, minimum salary $\$ 21,500$. 12-month, tenure-track appointment. Sick leave, 22 days vacation, Blue Cross Blue Shield, TIAA/CREF, and stale rebirement plans. To Apply: Send letter of application, resume, and the names and addresses of three references by the application deadline March 6, 1992, to: Voni B. Wyatt, Assistant to the Dean for Personnel, SEL Reference Librarian Search, The University of Alebama Libraries, P.O. Box 870266 Tuscaloosa, AL 35487-0265. The University of Alabama is an equal opportunity, affirmative action emplayer.

SENIOR ASSISTANT/LIBRARIAN. Provides the full range of aca demic reterence servicas. Performs database searches, instructs patrons in the use of CD-ROM and anline databases and the library's OPAC, actively particlpates in library instruction and reference activjties including some evening and weekend hours as assigned. Minimum qualifications: ALA-accredited degree 1 to 3 years of relevant experience in the above areas, excelient interpersonal and writing skills, knowiedge of bibliographic instruction techniques and practices. Desirable qualifications: Second master's degree, prejerably in the sciences. Permanent tenure-track appointment. Personal interview required. Finalist(s) will be invited to campus. Position will open July 1,1992 . Current salary range is $\$ 36,468$ to $\$ 63,948$. Submit a letter of application and resume by March 20, 1992, to: Library Pecruitment Committee, Califomis Siate University, San Bernardino, 5500 Universily Parkway, San Bernardino, CA 92407-2397 Files should be completed by April 30, 1992. Calitornia State Universty. San Bernardino is an equal opportunity, affirmative action, Section 504, Title IX employer.
SOCIAL SCIENCES BIBLIOGRAPHER. Responsible for developing and managing collections in the social sciences (excluding history). Maintains close contact with various UCLA depts., research centers, and acadernic programs in the social sciences including sociology, political science, anthropology, and the School of Sccial Weliare. Shares responsibility for ethnic studies with the American history and the American literature bibliographers, serv ing the ethnic studies research centers (Afro-American, Amsrican Indian, Asian American, Chicano). Duties include selecting mate rials, monitoring approval plans and budget expenditures, evaluating collections, and serving as liaison to the faculty. Graduate-level study (or equivalent) in one or more of the social sciences and a thorough understanding of research needs and the organization of scholarly literature are required. Practical experience in collection development and a demonstrated interest in scholarly activities (research. publications, or teaching) are desirable. Working knowledge of one or more languages in addition to Englısh is desirable. The ability to work effectively with faculty, students and library staff in a culturally diverse environment is essential. $\$ 28,668-\$ 59,316$. UCLA is an EOF/AA employer. Send application letter, a full resume, and the names of at least 3 reterences to: Rita A. Scherrei. Assoc. Univ. Librarian, Administrative and Personnel Services, University Research Library, University of California, Los Angeles, 405 Hilgard Ave., Los Angeles, CA 90024-1575. Candidates applying by March 31, 1992, will be given first consideration.

SOCIAL SCIENCES BIELIOGRAPHER AND ASSISTANT CHAIR, Smathers Library, University of Florida. Responsibslities: Administers, coordinates and provides leadership for the social sciences collection development and management operations of George A. Smathers Libraries and has primary responsibility for developing and managing a specitic social sciences collection. Analyzes University's social sciences programs, determines needs and priorities, and develops and implements plans to enhance library support of the research and instructional program. Assigns, trains, monitors, and evaluates staff assigned to the social sciences 
collection management program. Collaborates with librarians and the academic faculty to establish collection management policies and programs; and collaborates with library staff to develop public and techrical service support for them. Participates in defining library-wide collection management goals, objectives, strategies, performance criteria and materlals budgets. Participates in the library's publications and tund raising programs. Required: ALAaccredited MLS, advanced degree, preferably at the Ph.D. level, or commensurate experience in a social sciences tield; knowledge of and commitment to the goals of collection management and public service units; significant prolessional accomplishment relevant to the responsibilities of the position; excellent human relations, and communications skills. Minimum 5 years increasingly responsible experience, preferably in a research library collection managemen program. Preterred: Advanced degree in Psychology. Salary: Nego tiable depending an qualifications, minimum $\$ 35,000$ for 12 months. Benefits: Faculty status. Twenty-two days vacation, thirteen days sick leave annually. TIAAVCREF or other retirement options, usua insurance benetits, no state or local income tax. Send letter of application with resume and names, addresses, and telephone numbers of 3 professional references by April 15, 1992, to: Mar Bussell, Assistant Library Personnel Otficer, Gearge A. Smathers Libraries, 370 Library West, University of Florida, Gainesville, FL 32611. An AA/EEO Employer.

\section{ASSISTANT LIBRARIAN}

\section{College of Eastern Utah}

Reports to the Director of the Library and the Media Center. Primary duties involve Reference services, with an emphasis on developing closer ties between the library, students, faculty, and community. Other duties include Acquisitions, Cataloging, Circulation, Collection Development, Media Services. Must possess an ALA-accredited MLS degree, plus public services and technical services training. preferably in an academic library. Previous experience with IBM compatible computers as well as an automated library system, preferably Dynix, necessary. Must be a team player, able to work comfortably with paraprofessionals and student workers in an informal environment. Must also be able to work well with faculty, students, and the community. The College of Eastern Utah is a two-year community college beginning implementation of the Dynix system. Salary commensurate with training and experience. Institutional salary policy. Twelve-month position. Applications must be received by February 22, 1992 , including: vita, three letters of recommendation, and college transcripts.

\section{Personnel Office College of Eastern Utah 451 East 400 North Price, UT 84501 (801) 637-2120, ext. 240}

\section{UNIVERSITY LIBRARIAN UNIVERSITY of IOUISVILLE}

The University of Louisville invites applications and nominations for the position of University Librarian. The University of Louisville, established in 1798, is a state-supported urban instimution with approximately 24,000 students and 1,200 faculty. The city of Louisville has an attractive cultural life and is consistently rated as one of the most livable cities in the U.S.

The University Libraries is an academic unit that includes the following: a central library, a health sciences library, a science and engineering library, a music library, an art library, and a university archives. The unit employs 35 librarians and 94 staff and contains over $1,100,000$ volumes. Librarians have faculty status and aro expected to fulfill criteria for promotion and tenure. The University Librarian is tenured with academic rank.

Responsibilities include: management of the University Libraries system; accountability for a budget of over $\$ 5,000,000$; leadership of the library faculty and staff; application of computing and communications technology to support the Libraries' bibliographic collections and services; promotion of strong academic and community relationships; coordination of the Libraries' development activities. The University Librarian has the status of Dean, reports directly to the Provost, and serves as a member of the President's Execurive Cabiner.

Qualifications: relevant advanced degree (MLS from an ALA-accredited library school, or equivalent) required; second advanced degree desirable; progressively responsible administrative experience in a large academic library; record of innovative and energetic leadership, especially in the development of state-of-the-art library services, including access to documents in newly emerging electronic media; experience with fiscal management and fund raising; record of research and professional achievement that merits appointment at the level of full professor; firm grasp of current issues and trends in a complex library environment.

Salary negotiable beginning at $\$ 60,000$. Review of nominations and applications will begin on March 15, 1992. Send letters of nomination or application (including a curriculum vitae and the names, addresses, and telephone numbers of at least five references) to:

\section{Richard Griscom}

Chair, University Librarian Search Committee Office of the University Provost 201 Grawemeyer Hall University of Louisville Louisville, KY 40292

The University of Louisville is an Equal

Opportunity/Aflirmative Action Employer committed to cultura diversity. Wonen and minorities are encouraged to apply. 


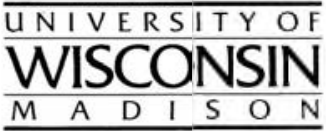

DIRECTOR OF THE GENERAL LIBRARY SYSTEM

\author{
University of Wisconsin-Madison
}

The Director of the General Library System (GLS) is the chief executiveand manager of the system, which consists of 15 campus libraries, and of its largest library, the Memorial Library. The Director of GLS is the principal representative and adviser for the Chancellor and Provost on university library coordination and policy; a member of the Chancellor's Administrative Council; co-chair of the campuswide administrative library planning body; and the primary liaison with other campus libraries and libraries throughout the University of Wisconsin System and the state.

ThetotalGLSbudget fromall sources exceeds $\$ 17$ million, including a state-funded $\$ 5.5$ millioncollection budget anda $\$ 7.7$ million personnelbudget. The GLSemploys an FIEstaff of approximately 100 professionals and 175 classified civil service staff. The Mernorial Library has a collection budget of $\$ 2.2$ millionand accounts for 75 FTE staff. The campus collection numbers over 5 millionvolumes and more than 40,000 current serial subscriptions.

The Director of GLS mustpossess demonstrated leadership qualities, astrong service orientation, and a proven record of managerial, interpersonal and administrative skills. Desirable qualifications include managerial and administrative experience within a system of research libraries; competence in and understanding of research library functions and technologies; active involvement in professional affairs; an advanceddegree in library science orarelated field. Candidates with appropriate academicacomplishments may also be considered for a faculty appointment. Salary commensurate with qualifications and experience. Minimum $\$ 90,000$.

The position will be available July 1, 1992. Only applications received by February 14, 1992 can be considered. Submit applications and nominations to:

\author{
Valters Nollendorts \\ Chair, Search and Screen Committee \\ University of Wisconsin-Madison \\ 134 Bascom Hall, 500 Lincoln Drive \\ Madison, Wisconsin 53706 \\ Telephone(608) 262-9337
}

The University of Wisconsin-Madison was founded in 1849. It is one of the largest land-grant universities in the United Slates. It has approximately 2,400 faculty, 5,000 professional and administrative staff, 9,000 classified employees, 43,000 students, and a budget of more than one billion dollars.

The University of Wisconsin-Madison is an equal opportunily, affimative action employer. Applications and nominations of women and minorities are encouraged. Upon request, the university is required to release an undifferentiated list of apphcants and nominees.

TECHNICAL SERVICES COORDINATOR. The Charles A. Dane Medical Library, Universiry of Vermont, invites applications for Technical Services Coardinator. The Dana Medical Library, the only academic medical library in Vermont, provides information services to the College of Medicine and the Schools of Nursing and Allied Heahth Sciences, as well as the Medical Center Hospital of Vermont, the University Health Center, and outreach services to hospitals and unaffiliated health care practitioners throughout the state. Working within a matrix management structure, the Coordinator reports to the Director of the Dana Library and supervises acquisitions, cataloging, serials, and binding within a NOTIS environment. As part of a team of information specialists, the position coordinates collection development and participates in other inlormation dissemination services. Requirements: Master's degree from an ALA-accredited school; 3 years library experience in an academic technical services area or equivalent; management style which fosters independent thinking; willingness to work on a collegial level with other taculty; excellent communications skills Preference given to applicants with integrated library system experience in a health sciences setting; working knowiedge of MeSH, NLM classification, MARC tormats and AACR2; tamiliarity with serials control collection management techniques; eligibility for membership in the Academy of Health Information Professionals. Appointment at the rank of Assistant Professor or above. Salary 
minimum $\$ 28,000$, depending upon qualifications, with excellent fringe benefits. Position open May 1, 1992. Applications received by March 1, 1992, will receive first consideration. Please submit letter of application, resume, and names, addresses, and phone numbers of 3 references to: Donna Lee, Chair, Search Committee, Charles A. Dana Medical Library, University of Vermont, Burlington, VT 05405. UVM is an equal opportunity, affirmative action employer. Women and people from diverse racial, ethnic, and cultural backgrounds are encouraged to apply.

UNIVERSITY LIBRARIAN, The University of North Carolina at Chapel Hill. The University of North Carolina at Chapel Hill invites applications and nominations for the position of University Librarlan. There are more than 2,100 faculty at the University, and over 23,000 students. The Ph.D. is offered in 62 fields, the University Librarian administers the Academic Affairs Librarıes which include Davis Library, the Wilson Special Callections Library, the House Undergraduate Library, and eight branch libraries. They hold over $\mathbf{3 . 8}$ million volumes and $\mathbf{3 . 3}$ million microforms. Library staff is comprised of 87 librarians, 162 career support staff, and approximately 300 part-time student employees. The current budget exceeds $\$ 13,000,000$. The University Librarian reports to the Provost. An elected Administrative Board representing all faculty ranks and divisions provides advice on policy matters. The University Libraries have a long history of cooperative collection development, resource sharing, joint development and operation of automated library systems and coordinated grant activities with Duke University and North Carolina State University in the Triangle Hesearch Libraries Network. It is essential that the Librarian be strongly committed to continuing this important relationship. Re sponsibilities: innovative management of the library units; evaluating and extending current services; keeping abreast of the rapid changes in information technology and developing strategies for implementation. The librarian will also play an important role in a major fund raising effort recently launched in conjunction with the University's bicentennial. Qualifications: Significant achievement in the administration of modern research libraries, including effective budget management; an understanding of the issues confronting higher education; a commitment to excellence in research and teaching; the ability to conceive and articulate to library staff University faculty and students, and potential donors a vision of the future of library resources and services. At a minimum a master's degree in library or information science from an ALA-accredited institution or extensive library experience is required. If the successful candidate possesses the Ph.D. degree and appropriate research and teaching credentials, he or she will also be consid. ered for appointment to the rank of Professor with tenure. Salary and benefits are competitive and commensurate with qualifications and experience. The University of North Carolina is an equa opportunity employer and encourages applications from women and minorities. Nominations and applications should be sent to: Richard Soloway, Chair, The University Librarian Search Committee, Department of History, Hamilton Hall CB\#3195, The UnIverslty of North Carolina at Chapel Hill, Chapel Hill, NC 27599-3195 Applications should include a letter with a complete statement of qualifications, curriculum vitae, and the names, addresses, and telephone numbers of four professional reterences. The Committee will begin to review applications atter March 1, 1992.

\section{Late Job Listings}

SENIOR ASSISTANT LIBRARIAN, California State University, Northridge, full-time, tenure-track position, Public Services Department, Reference Unit. MLS from an ALA accredited library school or equivalent. Salary range form $\$ 36,468-$ $\$ 39,984$. Send letter of application, resume, and address and phone number of three professional references to: Kris Ecklund, California State University Northridge, University Library, P.O. Box 1289, Northridge, CA 91328-1289. Application deadline is March 27, 1992. AA/EO, Title IX, Section 504 employer.

SCIENCE REFERENCE LIBRARIAN: Reference Librarian needed to provide reference assistance in the sciences. Participates in orientations and online searching, preparation of instructional materials and collection development. Requirements: MLS from ALA-accredited school; undergraduate degree in a science field (physics, chemistry, biology, geometry, math) preferred. Minimum 3 years professional experience, including online searching and microcomputer skills. Salary $\$ 25,000-\$ 29,000$ depending on qualifications. If interested, contact: Mary Keckley, Associate University Librarian, University of Texas El Paso Library, El Paso, TX 79968-0582, (Telephone: 915-747-5683 or FAX: 915-747-5327). Position will remain open until filled. UTEP is an EO/AA employer.

\section{HEAD, CIRCULATION AND ACCESS SERVICES DEPARTMENT, General} Libraries, Emory University. Available: June 1992. Responsibilities: Plan, organize, and direct the work of the Department and participate in the process of overall planning for Public Services in the 1990's. Exercise key role in coordinating circulation system activities for all Emory libraries, including additional development of the existing circulation subsystem of the DOBIS integrated library system. Work with other Emory public service units in the development and implementation of access policies and services. Reports to the Director of Public Services. Qualifications: MLS or equivalent from an ALA-accredited school; minimum of three years relevant experience in a university or public research library, including circulation and stack management; experience with an automated circulation system, prefer- 
ably an integrated system; demonstrated supervisory and managerial competency; strong interpersonal, communications, organizational, and analytical skills. Circulation and Access Services Department and General Libraries: The Department is responsible for all aspects of the circulation of library materials in the Woodruff Library; for stack management and planning, including storage facilities; for exit desk policies and procedures; for management of user access; for the implementation of security and emergency policies; and for coordination of monitoring of physical plant. The staff includes some twenty general staff positions and approximately twenty-five student assistants. The collections of the General Libraries total $1,200,000$ volumes (over 2,00,000 volumes for all Emory Libraries). The staff totals approximately 150 . Other resources are available in separate libraries for law, health sciences, theology and Oxford College. The Emory Libraries are members of the Association of Research Libraries and participate in OCLC and RLG. Beginning Salary: Dependent upon qualifications and experience, minimum for Librarian II, $\$ 26,000$; minimum for Librarian III, $\$ 31,000$. Comprehensive benefits package, including TIAA/CREF. Send letter of application, resume, and the names, addresses and telephone numbers of three references to: Chair, Search Committee for Head, Circulation and Access Services Department, Robert W. Woodruff Library, Emory University, Atlanta, GA 30322. Application deadline is April 10, 1992. Emory University is and equal opportunity, affirmative action employer.

CATALOGER OF IBERO-AMERICAN MATERIALS. Available: December 1, 1991. Description: Original cataloging of monographs plus consultation on cataloging of other formats in Spanish, Catalan, and Portuguese. Train and supervise two library assistants. Qualifications: Requires an ALA-accredited MLS; excellent knowledge of Spanish plus reading knowledge of Catalan and Portuguese; knowledge of and experience with OCLC, AACR2, and LC classification and subject headings required. Two or more years experience as a cataloger plus supervisory experience desirable. Academic background in Ibero American history and literature is preferred. Salary and Benefits: This position is a 12-month academic appointment with a starting salary of $\$ 22,000$ or more, depending on qualifications, and standard State benefits of annual leave, sick leave, and State or TIAA-CREF retirement plan. Deadline for application: March 1, 1992. To Apply: Send application letter, resume, and the names, addresses, and telephone numbers of three references to: Barbara A. DeLon, Library Personnel Office, CB\#3900, Davis Library, University of North Carolina at Chapel Hill, Chapel Hill NC 27599-3900. An equal opportunity, affirmative action employer.

DIRECTOR OF DEVELOPMENT RESEARCH. The Office of Development at the University of Idaho seeks a creative, specialized professional to collect, analyze, and provide detailed financial and bibliographical information about individuals, corporations, and foundations who are believed to have the potential for providing funding to priority programs at UI. Candidates must have a bachelor's degree; strong verbal and written communication skills; proven organizational skills; demonstrated ability with basic library research skills; and experience with personal computer, including word processors and data bases. Previous experience in prospect research and/or fund raising, a degree or coursework in Library Science, English, Journalism, or Business; and knowledge of Idaho political, business, and educational environments is desired. Salary range is $\$ 25,000-\$ 30,000$. This is a permanent, 12-month, exempt position reporting to the Executive Director of Development. Send a letter of application, resume, and the names, addresses, and telephone numbers of three references by February 21, 1992, to: Wanda Tennant, Chair, Director of Development Research Search Committee, University of Idaho Foundation, Inc., Moscow, ID 83843, (208)885-7069. EO/AAE 


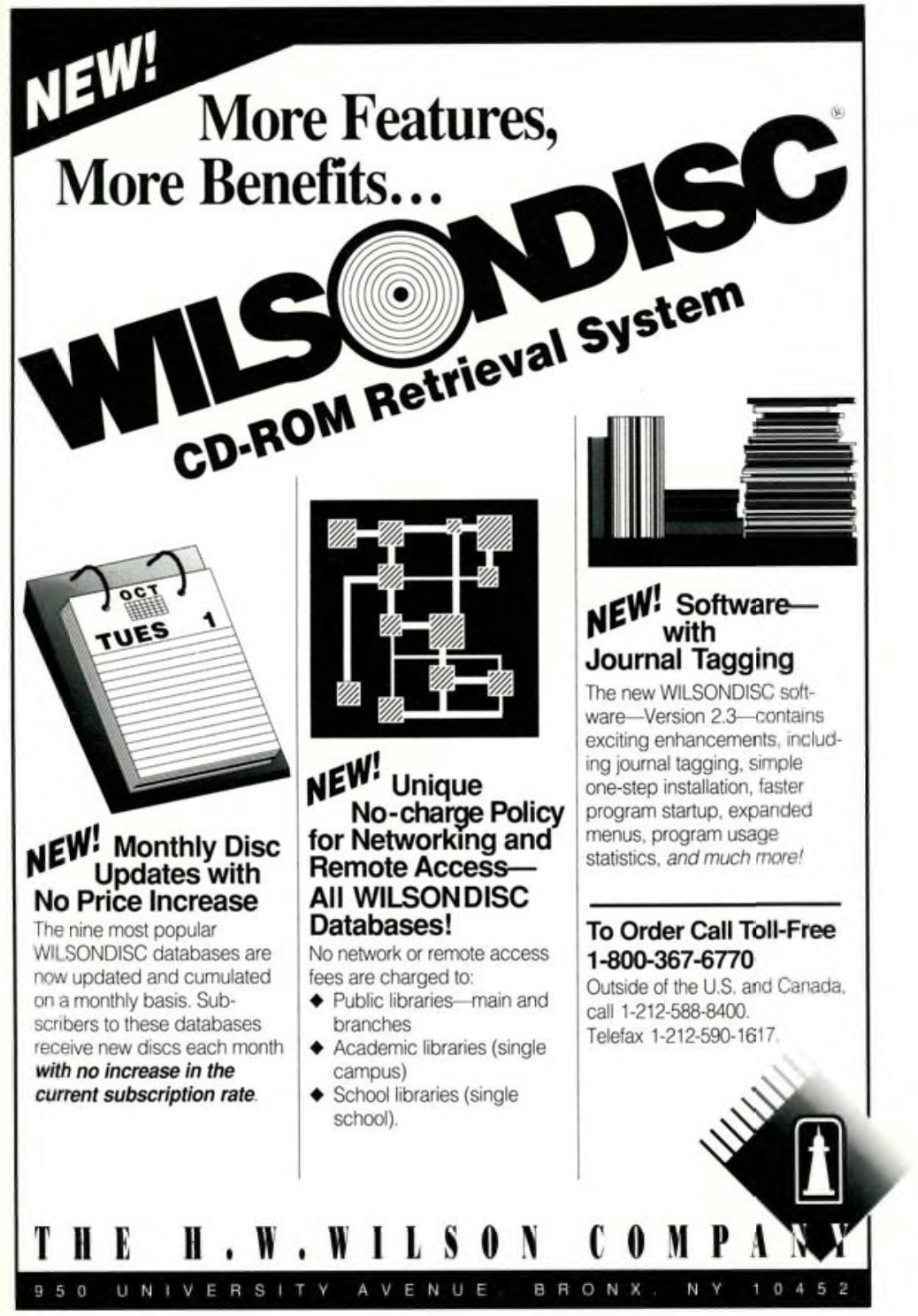




\section{We'll give you a spectacular view of the science world.}

NEW IN 1992:

Science Citation Index Compact Disc Edition with ABSTRACTS

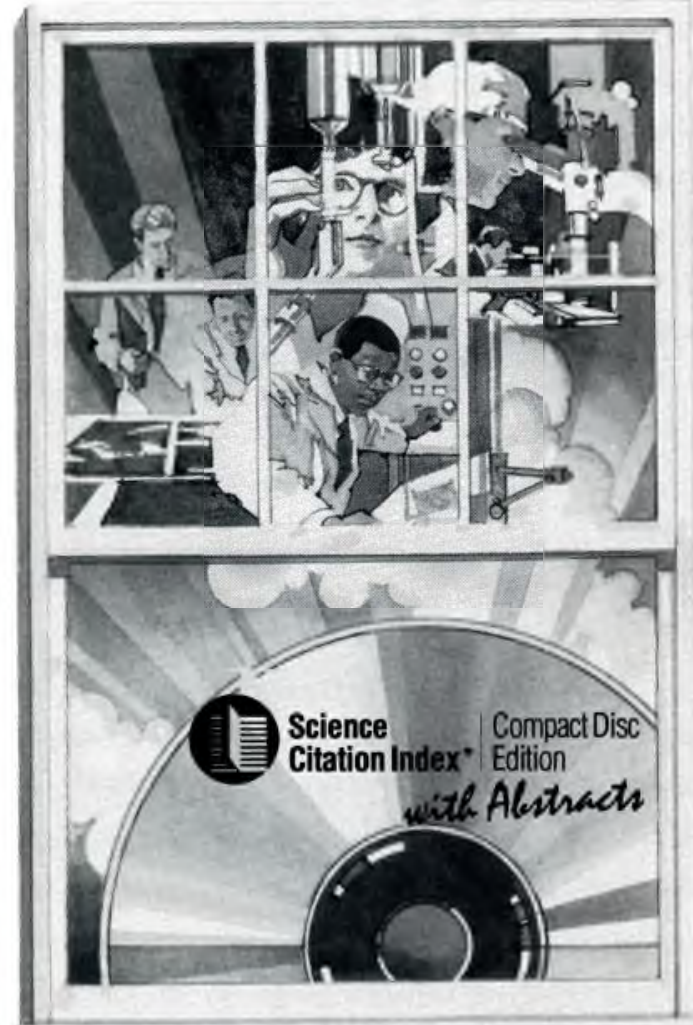

The best thing is, you need go no farther than your computer terminal - where you'll see it all in the Science Citation Index ${ }^{\infty}$ Compact Disc Edition.

With simple keystrokes, you're viewing the bibliographic records of 3,100 leading science journals...and running lightring fast searches to retrieve data on thousands of research topics.

Another keystroke acrivates Related Records ${ }^{\mathrm{TM}}$, the powerful searching mechanism available only from ISI. When you find one pertinent article, you're automatically led to many more, even if they have no title words in common! It's information you'd find no other way information that could have a dramatic impact on your research.

And newly available in 1992, searchable abstracts to make your search session even more complete. Reserve a free trial copy or demo diskette of the $\mathrm{SCI}^{\text {* }}$ CDE by calling $800-336-4474$, operator R451, or write the ISI office nearest you.

Instltute for Sclentiflc Informatlon

3501 Market Street, Philadelphia, PA 19104 U.S.A. Telephone: (215) 386-0100, Fax: (215) 386-2911 ISI European Branch: 132 High Street, Uxbridge, UB8 1DP U. K. Telephone: +44-895-270016

Fax: +44-895-256710 Telex: 933693 UK|S|

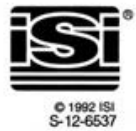

